\title{
Biocryomorphology: Integrating Microbial Processes with Ice Surface Hydrology, Topography, and Roughness
}

\author{
Joseph Cook ${ }^{1 *}$, Arwyn Edwards ${ }^{2,3}$ and Alun Hubbard ${ }^{4,5}$ \\ ${ }^{1}$ Department of Life and Natural Sciences, University of Derby, Derby, UK, ${ }^{2}$ Institute of Biological, Rural and Environmental \\ Sciences, Aberystwyth University, Aberystwyth, UK, ${ }^{3}$ Interdisciplinary Centre for Environmental Microbiology, Aberystwyth \\ University, Aberystwyth, UK, ${ }^{4}$ Department of Geology, Centre for Arctic Gas Hydrate, Environment and Climate, University of \\ Tromsø, Tromsø, Norway, ${ }^{5}$ Department of Geography, Centre for Glaciology, Aberystwyth University, Aberystwyth, UK
}

Keywords: cryosphere, biocryomorphology, glaciology, ecology, glacier

\section{INTRODUCTION}

Back in the late nineteenth century Polar explorers generated a body of literature on supraglacial microbe interactions that remains relevant today. In particular, Nordenskiöld (1872b) conceived that biologically aggregated dust ("cryoconite") was the "greatest enemy to the mass of ice," suggesting deglaciation was amplified by its albedo-lowering effect. However, these processes were only occasionally discussed during the twentieth century, leading some contemporary researchers to describe the cryosphere as the "forgotten biome" (Anesio and Laybourn-Parry, 2011). Arguably, this biome has been rediscovered and over the past decade the critical role of microbes in modulating glaciological processes has been widely acknowledged (Stibal et al., 2012a; Benning et al., 2014; Edwards et al., 2014a). Nevertheless, several key knowledge gaps identified by early explorers still await attention. We suggest that Nordenskiöld's work could provide a valuable white-paper directive for contemporary research into ice-microbe interactions. In particular, no models of ice surface dynamics yet include process-based descriptions of biological drivers (Benning et al., 2014). This is important because melt-stimulated algal blooms darken ice, further accelerating melt (Lutz et al., 2014) while biologically-driven aggregation darkens and prolongs the residence of light-absorbing inorganics on ice surfaces (e.g., Hodson et al., 2008). The complex, cross-scale interactions between microbes and ice surfaces remain weakly addressed. As Nordenskiöld (1872a,b) indicated, addressing these uncertainties requires integrating microbiology, biogeochemistry, near-surface hydrology, and the evolution of ice surfaces across various spatial scales.

Here, we propose the term "biocryomorphology" for the study of ice-microbe interactions and suggest that biocryomorphic insight is fundamental to understanding the role of biology in amplifying synoptic-scale supraglacial melt and hydrological processes (e.g., Stibal et al., 2012a; Benning et al., 2014; Mikkelsen et al., 2015). A framework for developing biocryomorphology as a concept within glaciology is proposed. We take inspiration from the analogous concept of "biogeomorphology" and the writings of Nordenskiöld (1872a,b); Nordenskiöld (1885), who understood the importance of cross-scale linkages between microbial activity, near-surface hydrology and micro- to macro-scale development ice surfaces.

Citation:

Cook J, Edwards A and Hubbard A (2015) Biocryomorphology: Integrating Microbial Processes with Ice Surface

Hydrology, Topography, and

Roughness. Front. Earth Sci. 3:78.

doi: 10.3389/feart.2015.00078

\section{CRYOCONITE HOLE MORPHOLOGY}

Following Kohshima (1987), Wharton et al. (1985), Hodson et al. (2008) established ice surfaces as habitats and highlighted their biogeochemical importance, catalyzing an abiotic to biotic 
paradigm shift in glaciology. Cryoconite holes were identified as especially biodiverse and active. These are depressions melted into ice by low-albedo aggregates of biotic and abiotic material. Typically, they are described as symmetrical cylinders with flat floors occupied by non-overlapping layers of cryoconite granules. Wharton et al. (1985) characterized them as discrete ecosystems with "distinct boundaries, energy flow and nutrient cycling," and more recent studies have determined microbial community structures using molecular techniques (e.g., Cameron et al., 2012; Edwards et al., 2014b). Cryoconite invariably comprises filamentous Cyanobacteria that “engineer" (Langford et al., 2010) aggregates, providing microhabitats for algae, heterotrophic bacteria, protozoa, fungi, and meiofauna. The contribution of these microbes to supraglacial carbon fluxes has been estimated over various spatial scales (Hodson et al., 2007; Cook et al., 2012; Chandler et al., 2015). To date, spatial variability in the relative abundances of the various cryoconite microbes (Stibal et al., 2012b, 2015; Vonnahme et al., 2015) and their carbon cycling potential (Anesio et al., 2009) have only been examined at macroscales. Moreover, cryoconite hole studies have almost exclusively been based on assumptions of steadystate equilibrium-independent of time-focussed on cylindrical holes and thereby decouple cryoconite ecology from changes in cryoconite hole shape and size.

While many cylindrical, flat-floored cryoconite holes exist (and may be the most common form, particularly in cold Antarctic ice where there is little supraglacial runoff) there is a diversity of hole shapes observable in the field (Figures 1D-F), especially in more temperate climates in the Alps, Svalbard, and Greenland. There, irregularly-shaped holes occur frequently, ranging from centimeters to meters in depth and diameter. The few studies that allude to this imply rapid geometric development toward a stable equilibrium state (Gribbon, 1979; Cook et al., 2010). Cook et al. (2010) argued that holes expand laterally to accommodate a "single grain layer" (SGL) of non-overlapping granules, exposing the maximum number of photoautotrophs to irradiance, influencing cryoconite biogeochemistry. Simultaneously, hole depth varies according to energy balance (Gribbon, 1979; Fountain et al., 2008), deepening when direct radiative forcing is high with respect to sensible heat flux. It follows that hole morphology can only be in steady-state if sediment flux is nil, incident radiation is constant, and the hole's ice substrate is evenly illuminated, hydrologically stable, and structurally uniform. Environments where such conditions persist are rare and infrequent-especially on faster-flowing, ablating margins of glaciers and ice sheets. Variable surface energy balance influences hole shapes directly (Gribbon, 1979) and indirectly by controlling the exaggeration and inversion of relief, creating spatial patterns of illumination and shade. This, along with hydrologic influences that vary on sub-diurnal to seasonal timescales (Cook et al., 2015) and heterogeneities in ice structure alter cryoconite distributions and derange lateral equilibration. Furthermore, energy balance is associated with near-surface hydrology, which develops seasonally at both poles and impacts cryoconite biogeochemistry (e.g., Fountain et al., 2004; Tranter et al., 2004; Irvine-Fynn et al., 2012; Bagshaw et al., 2013; Telling et al., 2014; Cook et al., 2015) and has been linked to granule mobility (Irvine-Fynn et al., 2011); however, potential feedbacks between near-surface hydrology, hole morphology and cryoconite biogeochemistry have so far been overlooked.

Hole morphology is therefore dynamic and lacking a welldefined chronology or end-member state, and cannot therefore indicate hole maturity. Moreover, viewing cryoconite holes as dynamic entities with morphologies that respond to their environments reinforces their role as melt amplifiers, since their contribution to ablation must increase during periods of expansion and/or migration. Since cryoconite microbes are sensitive to environmental conditions (Edwards et al., 2014b) and include "engineer" taxa (Langford et al., 2010), hole morphology should be viewed as a potential driver and indicator of microbial ecology. We should hence acknowledge co-evolution of ice surface roughness, near-surface hydrology, cryoconite hole morphology and microbial ecology in investigations of icemicrobe interactions.

\section{BIOCRYOMORPHOLOGY}

To address the uncertainties outlined above, we propose embedding "biocryomorphology" into glaciology to describe ice-organism interactions, with the aim of forging closer links between process glaciologists and polar biologists and developing a more holistic understanding of the cryosphere. The term is analogous to "biogeomorphology" (Viles, 1988) which is commonly used to describe biotic interactions with terrestrial landforms. Here, we provide suggestions for the development of biocryomorphology, taking cues from biogeomorphology and polar science history (Figures 1A-C).

Nordenskiöld's (1885) sketches show distinct hole morphologies linked to topography at the margin of the Greenland ice sheet. In plan-view hole sizes, shapes and positions were superimposed over contours; in profile distinct morphologies were shown on slopes and flats (Figures 1B,C). Nordenskiöld therefore tacitly linked hole morphology to mesoscale topography in the late 1800s. Since then, only one study has added insight; McIntyre (1984) described "D-shaped" holes with flat edges facing north and northward down-sloping hole floors, indicating an aspect control upon hole morphology. McIntyre's (1984) sketches also show thicker cryoconite layers against northern hole walls. Following Cook et al.'s (2010) model this suggests asymmetric expansion tending northwards away from topographically-controlled shading. Since topographic shading can cause non-uniformities in hole floor irradiance and melt rates, it follows that topography influences hole shape and, in turn, biogeochemistry. Beyond cryoconite holes, spatial patterns of algal bloom intensity are apparent, but are yet to be acknowledged in the literature. Slope angle and altitude might influence these blooms since the snowpack [which may inoculate ice surfaces (Hell et al., 2013) and represents a barrier to photosynthesis] likely melts faster on southfacing aspects than shady north-facing ones in the northern hemisphere and vice-versa. Blooms are thought to impact surface albedo and therefore have biocryomorphic significance, although biological darkening is yet to be quantified (Stibal 


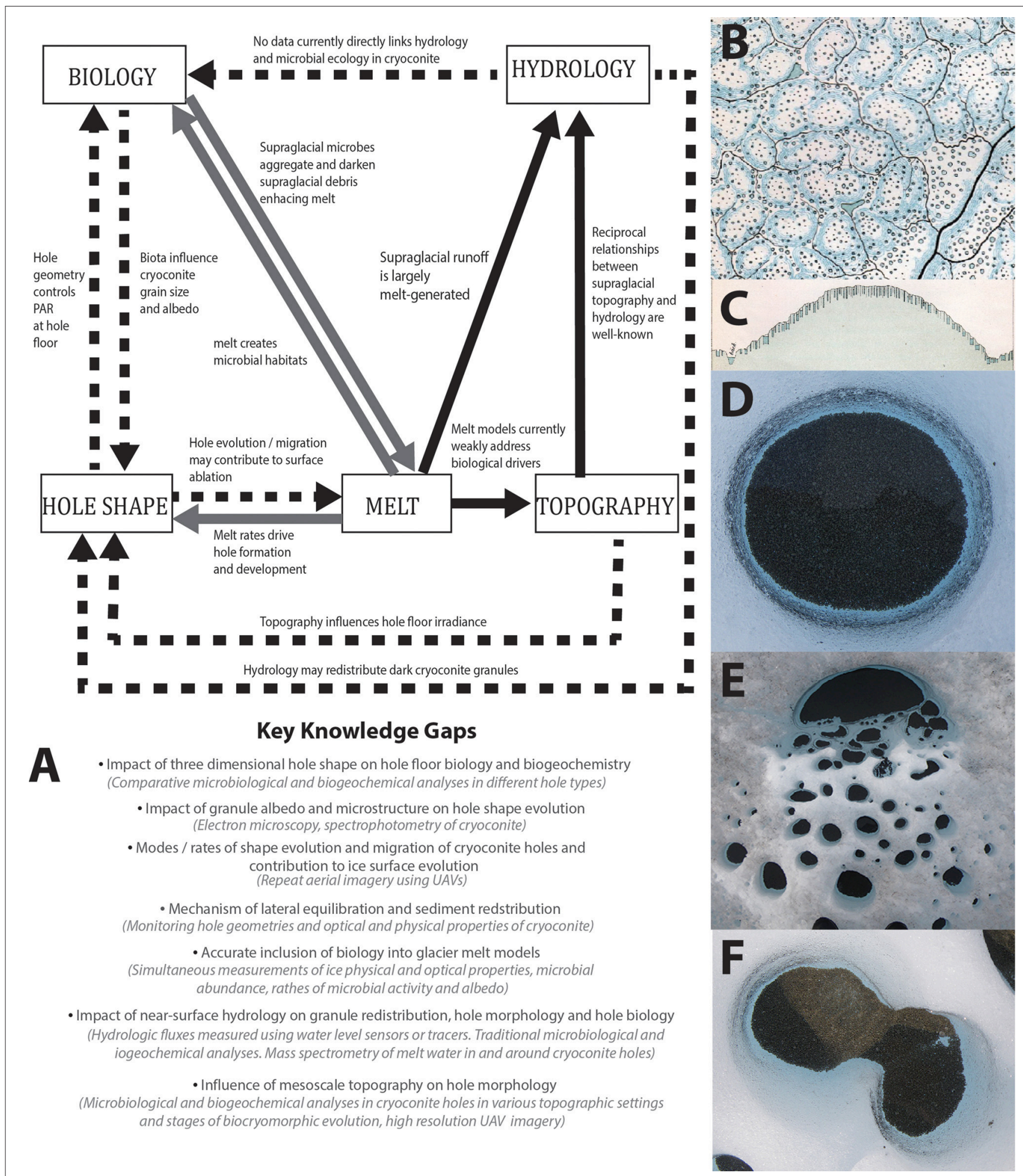

FIGURE 1 | (A) A conceptual model of biocryomorphology where dashed lines represent the most weakly understood interactions, gray lines show interactions that are understood conceptually but where much more data is required and solid lines represent well-understood processes. Bullet points highlight key knowledge gaps and suggestions for investigation methods are provided in brackets. (B) Extract from Nordenskiöld's (1885) field sketch showing cryoconite holes in plan view.

(C) Extract from Nordenskiöld's (1885) field sketches showing cryoconite holes in profile view. (D-F) Photographs showing diverse cryoconite hole shapes in plan view. 
et al., 2012a; Yallop et al., 2012). Constraining relationships between topography and biogeochemistry in cryoconite holes and algal blooms may prove fundamental for predicting microbially-mediated melt and biogeochemical cycling at the synoptic-scale.

Supraglacial hydrology also provides biocryomorphic control. In the Arctic, Irvine-Fynn et al. (2012) demonstrate that water flow through the near-surface porous ice ("weathering crust") facilitates microbial transport downglacier. Moreover, Edwards et al. (2011) infer that surface hydrology modulates cryoconite bacterial community structure and function. As Cook et al. (2015) discuss, cryoconite holes penetrate the weathering crust and offer long term storage for mineral and organic matter, as well as being natural piezometers indicative of meter-scale weathering crust hydrology. On Arctic ice, rather than being discrete entities occasionally linked by discrete flowpaths, cryoconite holes are sites of enhanced biological storage punctuating a glacier-wide depth-limited aquifer. This suggests that the entire glacier surface represents a spatially expansive, widely interconnected aquatic ecosystem (IrvineFynn and Edwards, 2014). In Antarctica, cryoconite holes are often entombed within glacier ice, closed from atmospheric and surface melt exchanges. However, several studies (Fountain et al., 2004, 2008; Tranter et al., 2004; Bagshaw et al., 2013; Telling et al., 2014) identify variable hydrologic connectivity between cryoconite holes that intermittently refreshes their hydrochemistry and stimulates microbial activity. In both polar environments, hydrological interconnectivity facilitates translocation of soluble materials and cells between cryoconite holes, impacting microbial ecology. Since cryoconite holes are foci for supraglacial biogeochemical transformations, delivery, storage, and elution of dissolved and suspended organic and inorganic matter from cryoconite holes could be critical for determining the quality and quantity of biogeochemical exports to other environments.

Hydrology is also a key influence on the shape, size and position of cryoconite holes. Rippin et al. (2015) shows that greater density of microscale channels is associated with rougher, darker ice. Since roughness is a key parameter in surface energy balance it likely influences hole morphology, which impacts cryoconite biogeochemistry (Cook et al., 2010) and reciprocally influences surface roughness. There is evidence for hydrological flow moving individual granules (Irvine-Fynn et al., 2011). In cryoconite holes permeating ice characterized by strong hydraulic gradients and high permeability, cryoconite could be redistributed toward the downstream hole wall, creating heterogeneity in granule layer thickness and deranging biocryomorphic development. Cryoconite granules likely form according to hydrologic mixing of biota and minerals (Langford et al., 2010), and may be eroded or disaggregated by hydraulic disturbance. In these circumstances, hydrological constraints are important drivers of biocryomorphology.

Biocryomorphology, from development of individual cryoconite holes to macroscale patterns of albedo and melt-is ultimately microbially driven. The term "ecosystem engineer" has been used to refer to cryoconite cyanobacteria (e.g., Langford et al., 2010; Edwards et al., 2014b) because they bind debris into discrete granules and cement them with extracellular polymers. This provides microhabitats for other organisms which comprise units of low albedo and high density that subsequently act to sculpt near-surface ice. The concept of biocryomorphic equilibration suggests that conditions promoting net autotrophy are attractors toward which cryoconite entities evolve, albeit ones that themselves change in response to the abiotic environment. Biocryomorphic processes are therefore contingent upon biology, but also define the conditions in which biological activity occurs. By altering hole floor conditions, biocryomorphic development likely influences cryoconite microbial ecology which may feedback into granule albedo and stability, hydrologic translocation of cells and nutrients, and ice surface topography. The coevolutionary processes linking microbial ecology, granule stabilization, near-surface hydrology, ice topography, and habitat maintenance-and how these combine to amplify surface meltmerit investigation if we are to fully understand ice-microbe interactions.

\section{SUMMARY}

Accurate prediction of microbially-mediated melt and biogeochemical fluxes requires consideration of spatiotemporal variability in ice-microbe interactions. Foremost, cryoconite holes should be viewed as morphologically changeable nodes of immobilized biomass within a spatially expansive aquatic ecosystem. Habitat shape and size, ice surface topography and near-surface hydrology require integration into understanding of supraglacial microbiology. These variables define and-in turn-are defined by microbial activity via feedbacks that are currently poorly defined and unquantified. We propose that biocryomorphology should be established as a concept uniting glaciology with biogeochemistry, glacio-biology, glacio-meteorology, melt, and climate modeling to achieve process-based insight into the ecological dynamics operating across the surface of earth's ice masses and that play a primary role in modulating their response to atmospheric forcing.

\section{ACKNOWLEDGMENTS}

Research into biocryomorphic evolution has been funded by Royal Society grant PRESTIGE (RG130314) to AE, plus support to JC from Gino Watkins Memorial Fund, Andrew Croft Memorial Fund, British Society for Geomorphology, Scottish Arctic Club, Gilchrist Educational Trust, Mount Everest Foundation and Gradconsult. Initial work into lateral equilibration was funded by NERC Doctoral Training Grant NE/G524152/1 to JC. AH acknowledges salary support from the Research Council of Norway (Grant 223259). 


\section{REFERENCES}

Anesio, A. M., and Laybourn-Parry, J. (2011). Glaciers and ice sheets as a biome. Trends Ecol. Evol. 27, 219-225. doi: 10.1016/j.tree.2011. 09.012

Anesio, A. M., Hodson, A. J., Fritz, A., Psenner, R., and Sattler, B. (2009). High microbial activity on glaciers: importance to the global carbon cycle. Glob. Change Biol. 15, 955-960. doi: 10.1111/j.1365-2486.2008. 01758.x

Bagshaw, E., Tranter, M., Fountain, A. G., Welch, K. A., Basagic, H. J., and Lyons, W. B. (2013). Do cryoconite holes have the potential to be significant sources of C, N and P to downstream depauperate ecosystems of Taylor Valley, Antarctica? Arct. Antarct. Alpine Res. 45, 440-454. doi: 10.1657/1938-424645.4.440

Benning, L. G., Anesio, A. M., Lutz, S., and Tranter, M. (2014). Biological impact on Greenland's albedo. Nat. Geosci. 7, 691. doi: 10.1038/ ngeo 2260

Cameron, K., Hodson, A. J., and Osborn, M. (2012). Carbon and nitrogen biogeochemical cycling potentials of supraglacial cryoconite communities. Polar Biol. 35, 1375-1393. doi: 10.1007/s00300-0121178-3

Chandler, D. M., Alcock, J. D., Wadham, J. L., Mackie, S. L., and Telling, J. (2015). Seasonal changes of ice surface characteristics and productivity in the ablation zone of the Greenland Ice Sheet. Cryosphere 9, 487-504. doi: $10.5194 /$ tc- $9-487-2015$

Cook, J., Hodson, A., Telling, J., Anesio, A., Irvine-Fynn, T., and Bellas, C. (2010). The mass-area relationship within cryoconite holes and its implications for primary production. Ann. Glaciol. 51, 106-110. doi: 10.3189/172756411795932038

Cook, J. M., Hodson, A. J., Anesio, A. M., Hanna, E., Yallop, M., Stibal, M., et al. (2012). An improved estimate of microbially mediated carbon fluxes from the Greenland ice sheet. J. Glaciol. 58, 1098-1108. doi: 10.3189/2012JoG1 2J001

Cook, J. M., Hodson, A. J., and Irvine-Fynn, T. D. L. (2015). Supraglacial weathering crust dynamics inferred from cryoconite hole hydrology. Hydrol. Process. doi: 10.1002/hyp.10602. [Epub ahead of print].

Edwards, A., Anesio, A. M., Rassner, S. M., Sattler, B., Hubbard, B., Perkins, W. T., et al. (2011). Possible interactions between bacterial diversity, microbial activity and supraglacial hydrology of cryoconite holes in Svalbard. ISME J. 5, 150-160. doi: 10.1038/ismej.2010.100

Edwards, A. E., Irvine-Fynn, T., Mitchell, A. C., and Rassner, S. M. (2014a). A germ theory for glacial systems? WIREs Water 1, 331-340. doi: 10.1002/ wat 2.1029

Edwards, A. J., Mur, L. A. J., Girdwood, S. E., Anesio, A. M., Stibal, M., Rassner, S. M. E., et al. (2014b). Coupled cryoconite ecosystem structure-function relationships are revealed by comparing bacterial communities in Alpine and Arctic glaciers. FEMS Microb. Ecol. 89, 222-237. doi: 10.1111/1574-6941. 12283

Fountain, A. G., Nylen, T. H., Tranter, M., and Bagshaw, E. (2008). Temporal variations in physical and chemical features of cryoconite holes on Canada Glacier, McMurdo Dry Valleys, Antarctica. J. Geophys. Res. 113, G01S92. doi: 10.1029/2007JG000430

Fountain, A. G., Tranter, M., Nylen, T. H., Lewis, K. J., and Mueller, D. R. (2004). Evolution of cryoconite holes and their contribution to meltwater runoff from glaciers in the McMurdo Dry Valleys, Antarctica. J. Glaciol. 50, 35-45. doi: $10.3189 / 172756504781830312$

Gribbon, P. W. (1979). Cryoconite holes on Sermikaysak, West Greenland. J. Glaciol. 22, 177-181.

Hell, K., Edwards, A., Zarsky, J., Podmirseg, S. M., Girdwood, S., Pachebat, J. A., et al. (2013). The dynamic bacterial communities of a melting High Arctic glacier snowpack. ISME J. 7, 1814-1826. doi: 10.1038/ismej. 2013.51

Hodson, A. J., Anesio, A. M., Ng, F., Watson, R., Quirk, J., Irvine-Fynn, I., et al. (2007). A glacier respires: quantifying the distribution and respiration $\mathrm{CO}_{2}$ flux of cryoconite across Arctic supraglacial ecosystem. J. Geophys. Res. 112, G04S36. doi: 10.1029/2007JG000452
Hodson, A., Anesio, A. M., Tranter, M., Fountain, A., Osborn, M., Priscu, J., et al. (2008). Glacial ecosystems. Ecol. Monogr. 78, 41-67. doi: 10.1890/070187.1

Irvine-Fynn, T. D. L., Bridge, J. W., and Hodson, A. J. (2011). In situ quantification of supraglacial cryoconite morpho-dynamics using timelapse imaging: an example from Svalbard. J. Glaciol. 57, 651-657. doi: 10.3189/002214311797409695

Irvine-Fynn, T. D. L., Edwards, A., Newton, S., Langford, H., Rassner, S. M., Telling, J., et al. (2012). Microbial cell budgets of an Arctic glacier surface quantified using flow cytometry. Environ. Microbiol. 14, 2998-3012. doi: 10.1111/j.1462-2920.2012.02876.x

Irvine-Fynn, T. D. L., and Edwards, A. (2014). A frozen asset: the potential of flow cytometry in constraining the glacial biome. Cytom. Part A 85, 3-7. doi: 10.1002/cyto.a.22411

Kohshima, S. (1987). "Glacial biology and biotic communities," in Evolution and Coadaptation in Biotic Communities, Faculty of Science, Kyoto University, eds S. Kawano, J. H. Connell, and T. Hidaka (Tokyo: University of Tokyo Press), 77-92.

Langford, H., Hodson, A., Banwart, S., and Bøggild, C. (2010). The microstructure and biogeochemistry of Arctic cryoconite granules. Ann. Glaciol. 51, 87-94. doi: 10.3189/172756411795932083

Lutz, S., Anesio, A. M., Jorge Villar, S. E., and Benning, L. G. (2014). Variations of algal communities cause darkening of a Greenland glacier. FEMS Microbiol. Ecol. 89, 402-414. doi: 10.1111/1574-6941. 12351

McIntyre, N. F. (1984). Cryoconite hole thermodynamics. Can. J. Earth Sci. 21, 152-156. doi: 10.1139/e84-016

Mikkelsen, A., Hubbard, A., MacFerrin, M., Box, J., Doyle, S., Fitzpatrick, A., et al. (2015). Extraordinary runoff from the Greenland Ice Sheet in 2012 amplified by hypsometry and depleted firn-retention. Cryosph. Discuss. 9, 1-34. doi: 10.5194/tcd-9-4625-2015

Nordenskiöld, A. E. (1872a). I.-Account of an expedition to Greenland in the year 1870. Geol. Mag. 9, 289-306. doi: 10.1017/S00167568004 65143

Nordenskiöld, A. E. (1872b). V. - Account of an expedition to Greenland in the year 1870. Geol. Mag. 9, 355-368. doi: 10.1017/S0016756800465325

Nordenskiöld, A. E. (1885). Den Andra Dicksonska Expeditionen till Gronland. Stockholm: F \& G Beijers Forlag. Accessed via Project Runeberg. Available online at: http://runeberg.org/polexp1883/

Rippin, D. M., Pomfret, A., and King, N. (2015). High resolution mapping of supra-glacial drainage pathways reveals link between micro-channel drainage density, surface roughness and surface reflectance. Earth Surf. Proc. Landforms 40, 1279-1290. doi: 10.1002/esp.3719

Stibal, M., Šabacká, M., and Žárský, J. (2012a). Biological processes on glacier and ice sheet surfaces. Nat. Geosci. 5, 771-774. doi: 10.1038/ ngeo1611

Stibal, M., Telling, J., Cook, J., Mak, K. M., Hodson, A., and Anesio, A. M. (2012b). Environmental controls on microbial abundance on the Greenland ice sheet: a multivariate analysis approach. Microb. Ecol. 63, 74-84. doi: 10.1007/s00248011-9935-3

Stibal, M., Schostag, M., Cameron, K. A., Hansen, L. H., Chandler, D. M., Wadham, J. L., et al. (2015). Different bulk and active bacterial communities in cryoconite from the margin and interior of the Greenland ice sheet. Environ. Microbiol. Rep. 7, 293-300. doi: 10.1111/1758-2229. 12246

Telling, J., Anesio, A. M., Tranter, M., Fountain, A. G., Nylen, T., Hawkings, J. et al. (2014). Spring thaw ionic pulses boost nutrient availability and microbial growth in entombed Antarctic Dry Valley cryoconite holes. Front. Microbiol. 5:694. doi: 10.3389/fmicb.2014.00694

Tranter, M., Fountain, A. G., Fritsen, C. H., Lyons, W. B., Priscu, J. C., Statham, P. J., et al. (2004). Extreme hydrochemical conditions in natural microcosms entombed within Antarctic ice. Hydrol. Process. 18, 379-387. doi: 10.1002/hyp. 5217

Viles, H. A. (1988). Biogeomorphology. Oxford: Blackwell. 365.

Vonnahme, T. R., Devetter, M., Zarsky, J. D., Sabacka, M., and Elster, J. (2015). Controls on microalgal community structures in cryoconite holes 
upon high Arctic glaciers in Svalbard. Biogeosci. Discuss 12, 11751-11795. doi: 10.5194/bgd-12-11751-2015

Wharton, R. A. Jr., McKay, C. P., Simmons, G. M. Jr., and Parker, B. C. (1985). Cryoconite holes on glaciers. Bioscience 35, 449-503. doi: 10.2307/13 09818

Yallop, M. L., Anesio, A. M., Perkins, R. G., Cook, J., Telling, J., Fagan, D., et al. (2012). Photophysiology and albedo-changing potential of the ice-algal community on the surface of the Greenland ice sheet. ISME J. 6, 2302-2313. doi: 10.1038/ismej.20 12.107
Conflict of Interest Statement: The authors declare that the research was conducted in the absence of any commercial or financial relationships that could be construed as a potential conflict of interest.

Copyright (C) 2015 Cook, Edwards and Hubbard. This is an open-access article distributed under the terms of the Creative Commons Attribution License (CC BY). The use, distribution or reproduction in other forums is permitted, provided the original author(s) or licensor are credited and that the original publication in this journal is cited, in accordance with accepted academic practice. No use, distribution or reproduction is permitted which does not comply with these terms. 